\title{
Assessing genotoxic effects in fish from a marine protected area influenced by former mining activities and other stressors
}

\author{
Paloma Kachel Gusso-Choueri a,b,c,*, Rodrigo Brasil Choueri d, Gustavo Souza Santos a,e, \\ Giuliana Seraphim de Araújo c,f , Ana Carolina Feitosa Cruz c,f , Tatiana Stremel ${ }^{\mathrm{g}}$, Sandro Xavier de Campos $^{\mathrm{g}}$, \\ Marta Margarete Cestari ${ }^{\mathrm{a}, \mathrm{e}}$, Ciro Alberto Oliveira Ribeiro ${ }^{\mathrm{a}, \mathrm{b}}$, Denis Moledo de Sousa Abessa ${ }^{\mathrm{c}}$ \\ a Graduate Program in Ecology and Conservation, Federal University of Paraná (UFPR), CP 19031, CEP 81531-990 Curitiba, PR, Brazil \\ b Cellular Toxicology Laboratory, Department of Cellular Biology, Federal University of Paraná (UFPR), CP19031, 81531-990 Curitiba, PR, Brazil \\ c Laboratory for the Study of Aquatic Pollution and Ecotoxicology (NEPEA), São Paulo State University, São Vicente Campus (UNESP Campus do Litoral Paulista), \\ Praça Infante Dom Henrique, s/n, CP 11330-900 São Vicente, SP, Brazil \\ d Department of Marine Sciences, Federal University of São Paulo, Santos Campus (UNIFESP — Santos), Av. Almirante Saldanha da Gama, 89, CP 11030-490 Santos, SP, Brazil \\ e Genetics Department, Federal University of Paraná (UFPR), 81531-990 Curitiba, PR, Brazil \\ ${ }^{\mathrm{f}}$ Institute of Oceanography, University of São Paulo (IOUSP), Praça do Oceanográfico, 191, CEP 05508-120 São Paulo, SP, Brazil \\ ${ }^{g}$ Research Group on Environmental and Sanitary Analytical Chemistry (QAAS), Ponta Grossa State University, Av. General Carlos Cavalcanti, 4748, CEP 84030-900 Ponta Grossa, Brazil
}

\section{A R T I C L E I N F O}

\section{Article history:}

Received 23 June 2015

Received in revised form 12 January 2016

Accepted 16 January 2016

Available online 25 January 2016

\section{Keywords:}

Estuary

Weight of evidence

Environmental quality assessment

Genotoxicity

Biomarkers

Multivariate approach

\begin{abstract}
A B S T R A C T
The goal of the current study was to evaluate different genotoxicity tools in order to assess a marine protected area (MPA) affected by former mining activities and urban settlements. A catfish (Cathorops spixii) was analyzed for genotoxic effects at the (i) molecular and at the (ii) chromosomal levels. Through factor analysis, genotoxicity was found to be linked to levels of metals bioaccumulated and PAH metabolites in the bile. Micronucleus and nuclear alteration were less vulnerable to the effects of confounding factors in mildly contaminated areas since they were more frequently associated with bioaccumulated metals than the DNA analysis. The different genotoxicity responses allowed for the identification of sources of pollution in the MPA. This approach was important for detecting environmental risks related to genotoxic contaminants in a mildly contaminated MPA.
\end{abstract}

c) 2016 Elsevier Ltd. All rights reserved.

\section{Introduction}

Metal contamination of aquatic ecosystems due to mining activities is of great environmental concern on a global scale and is one of the most serious threats to aquatic environments worldwide (Zhuang et al., 2014). This concern has arisen partly because mining activities are commonly performed but not controlled or monitored (Rybicka, 1996). Additionally, mine waste and tailings can have severe negative effects on the regions surrounding the mines (Fernández-Caliani et al., 2009). This effect often occurs because pollutants tend to be transported mainly via water (e.g. acid mine drainage) and air (atmospheric deposition, wind-blown particulate matter), and thus accumulate in various environmental compartments. Toxic metals from mining activities can therefore potentially impact the biota and human beings alike

\footnotetext{
* Corresponding author at: Laboratory for the Study of Aquatic Pollution and Ecotoxicology (NEPEA), São Paulo State University, São Vicente Campus (UNESP Campus do Litoral Paulista), Praça Infante Dom Henrique, s/n, CP 11330-900 São Vicente, SP, Brazil.

E-mail address: pchoueri@ufpr.br (P.K. Gusso-Choueri).
}

(e.g. Riba et al., 2005; Taylor et al., 2014; Camizuli et al., 2014; Molina-Villalba et al., 2015).

The Ribeira de Iguape River (RIR), located in southeastern Brazil, is an important mining region and represents an example of uncontrolled mining activity. Lead mines operated during the twentieth century, and their waste products were discharged into the river or on the river banks. High levels of metals such as $\mathrm{Pb}, \mathrm{Zn}, \mathrm{Cu}, \mathrm{Cr}$, and As have been recorded in river waters, bottom sediments, and suspended sediments in river headwaters (Eysink et al., 1998; Moraes et al., 2003; Guimarães and Sígolo, 2008). The RIR flows toward the Estuarine System of the Cananeia-Iguape-Peruíbe Environmental Protection Area (APA-CIP), recognized as a UNESCO World Natural Heritage Site. Metals in the APA-CIP estuarine sediments, which have been found at low levels in the past, increased substantially after the construction of an artificial connection between the river and the estuary (Mahiques et al., 2009). Recent studies have reported metals at moderate levels in the sediments from the estuary, quantities which have been attributed to the former mining activities as well as to contamination from urban settlements within the APA-CIP (Azevedo et al., 2011; Cruz et al., 2014; Gusso-Choueri et al., 2015). 
A multitude of ecotoxicological approaches and tools, from molecular testing to ecological response assessments, have been proposed over the last few decades for environmental assessment and monitoring (Van Straalen, 2003). Their application, however, has been tested and validated only at highly contaminated sites (e.g. Adams and Greeley, 2000; Galloway et al., 2004; Choueri et al., 2010; Torres et al., 2015). Mildly contaminated sites can also affect the health of the aquatic biota, since the organisms are subjected to long-term exposure (Nipper et al., 1998). This is the case of many marine protected areas (MPAs) influenced by urban or industrial settlements; these areas may be subjected to perhaps relatively moderate but nonetheless continuous inputs of contaminants produced on their outermost boundaries (Chou et al., 2004; Pozo et al., 2009; Perra et al., 2011; Araujo et al., 2013).

However, in mildly contaminated areas, cause-and-effect relationships between contamination and toxicity may not be as straightforward as they are at highly contaminated sites, especially in complex physical and chemical settings such as estuaries (Choueri et al., 2009). Tests on biological responses must be sensitive to low levels of contaminants, but still representative of an actual or potential risk to the individual organism or the population. Genotoxic responses may trigger a damaging chain of biological changes (e.g. reproduction disturbances, growth inhibition, carcinogenesis), some of which can be passed on to the next generations. These responses may also lead to a loss of genetic diversity (Mitchelmore and Chipman, 1998; Jha, 2004; Baršienė et al., 2013).

Different types of DNA damage may occur when organisms are exposed to environmental contamination. These types of damage include single- and double-strand breaks, inter-strand and intra-strand crosslinks, DNA adducts, and DNA protein crosslinks (Wood et al., 2001). Some metals and PAHs (especially high molecular weight PAHs) are known to cause genotoxicity. DNA damage caused by such contaminants can be characterized into three phases: (i) the formation of adducts with toxic molecules, followed by (ii) secondary DNA modifications, including single- and double-strand break, changes to DNA repair, base oxidation, and crosslinks (Fonseca et al., 2014), and an advanced stage (iii) in which cells present altered functions, cell proliferation, mutagenesis, and eventually carcinogenesis (Monserrat et al., 2007).

The quantification of DNA strand breaks (via electrophoresis or fluorescence measurement) is considered a sensitive indicator of genotoxicity at the molecular level (Olive, 1988; Gagne and Blasé, 1995; Silva et al., 2012; Maranho et al., 2012; Parolini et al., 2013). At the chromosomal level, the formation of micronuclei and nuclear abnormalities in fish erythrocytes has also been successfully used as indicators of genotoxicity caused by environmental contamination (e.g. Souza and Fontanetti, 2012; Hoshina et al., 2008). Several studies have reported increased frequencies of micronuclei and nucleus abnormalities in fish cells after exposure to different metals under both field and laboratory conditions (Al-Sabti and Metcalfe, 1995; Cavas et al., 2005; Cavaş, 2008; Isani et al., 2009; Yadav and Trivedi, 2009).

The Marine Strategy Framework Directive (2008/56/CE) has recently proposed the use of genotoxicity endpoints as a tool to help characterize the biological status of marine water bodies. In addition, different genotoxicity assays have been used in environmental monitoring programs (e.g. ICES Working Group on Biological Effects of Contaminants and the Mediterranean Pollution Programme) (Davies and Vethaak, 2012). Although this approach has been widely used for environmental quality assessment and monitoring, no attempts have been made to assess the suitability of these tools for monitoring mildly contaminated sites or MPAs. These studies on mildly contaminated sites are important because genotoxic responses can be affected by many factors, including natural environmental conditions, diet, and hormonal status (Mitchelmore and Chipman, 1998). These confounding factors may be exacerbated from mildly contaminated environments.

The current study aimed to evaluate different genotoxicity tools used on fish in order to assess an MPA affected by former land-based mining activities and current urban settlements. We hypothesized that the different genotoxicity endpoints would be positively associated with contaminant body burden. We also hypothesized that different tissues would respond differently to the contamination.

Cathorops spixii was tested for genotoxic effects through (i) the quantification of DNA damage in different tissues by means of two different methodologies (the comet assay with blood tissue, and the alkaline precipitation assay with kidney, liver, and gill tissues), and (ii) cytogenotoxicity assessment, which was performed using the micronucleus test (MN) and tests on nuclear alterations (NA) in erythrocytes. The bioindicator specie ( $C$. spixii) was chosen because it is a species potentially exposed to contaminated sediments in the estuary, since it has demersal habits, preys mainly upon zoobenthos (especially crustaceans and polychaetes) (Fishbase, 2014) and spends its whole life cycle in muddy-bottom estuaries (Azevedo et al., 1999). Additionally, C. spixii is considered as an important artisanal fishing resource in tropical and sub-tropical South American Atlantic coasts (Melo and Teixeira, 1992; Álvarez-León and Rey-Carrasco, 2003).

The relationship between environmental contamination and genotoxicity was assessed by integrating genotoxicity data with metal body burdens (liver and muscle) and levels of PAH metabolites in bile by using a multivariate approach. The results of this study can subsidize the definition of suitable genotoxic tools to assess and monitor MPAs.

\section{Materials and methods}

\subsection{Study area}

The Cananéia-Iguape-Peruíbe Environmental Protection Area, or the APA-CIP $\left(24^{\circ} 40^{\prime} \mathrm{S}\right.$ and $25^{\circ} 05^{\prime} \mathrm{S}$ ) (Fig. 1 ) is an estuarine-lagoon ecosystem recognized by UNESCO as part of the Biosphere Reserve of the Atlantic Rainforest. It is an area of priority to be included on the list of Brazilian wetlands of international importance within the scope of the Ramsar Convention (Brazil, 2012). The region is on the list of UNESCO World Heritage Sites.

The main freshwater contributor to the estuarine lagoon is the Ribeira de Iguape River (RIR), which meets the lagoon through a water channel known as Valo Grande. This lagoon deviates approximately $70 \%$ of the river toward the lagoon waters. For many years, mine tailing and metallurgical slags such as blast furnace were directly dumped into the RIR. After the establishment and enforcement of Brazilian environmental laws in the early 1990s, the mining industry halted its release of waste into the river, but began disposing of it on the river banks instead. The waste and riverbanks were exposed to weathering and subjected to lixiviation (Guimarães and Sígolo, 2008; Abessa et al., 2014).

High levels of some metals ( $\mathrm{Pb}, \mathrm{Zn}, \mathrm{Cu}, \mathrm{Cr}$ ) and As were recorded in the river waters, as well as on riverbeds and in suspended sediments (Eysink et al., 1998; Corsi and Landim, 2003; Moraes et al., 2003; Guimarães and Sígolo, 2008). Meanwhile, in the estuarine lagoon, metals were found at only moderate levels in the sediments (Mahiques et al., 2009) as defined by international Sediment Quality Guidelines (Long et al., 1995; Environment Canada and Ministère du Développement durable, de l'Environnement et des Parcs du Québec, 2007).

In addition to former mining activities, other sources of contaminants to the APA-CIP include the three cities placed within the limits of the protection area (Iguape, Ilha Comprida, and Cananéia), with a total estimated population of approximately 51,900 inhabitants (IBGE, 2014), and which lack adequate sanitation infrastructure (Morais and Abessa, 2014).

\subsection{Fish collection and sample preparation}

The sampling sites were set with the aim of encompassing the main potential contaminant sources along the APA-CIP (Fig. 1). Thus, site P1 is the closest to the mouth of the RIR, and site P4 is the closest to the city of Cananéia. Fifteen specimens of $C$. spixii were collected at each sampling 


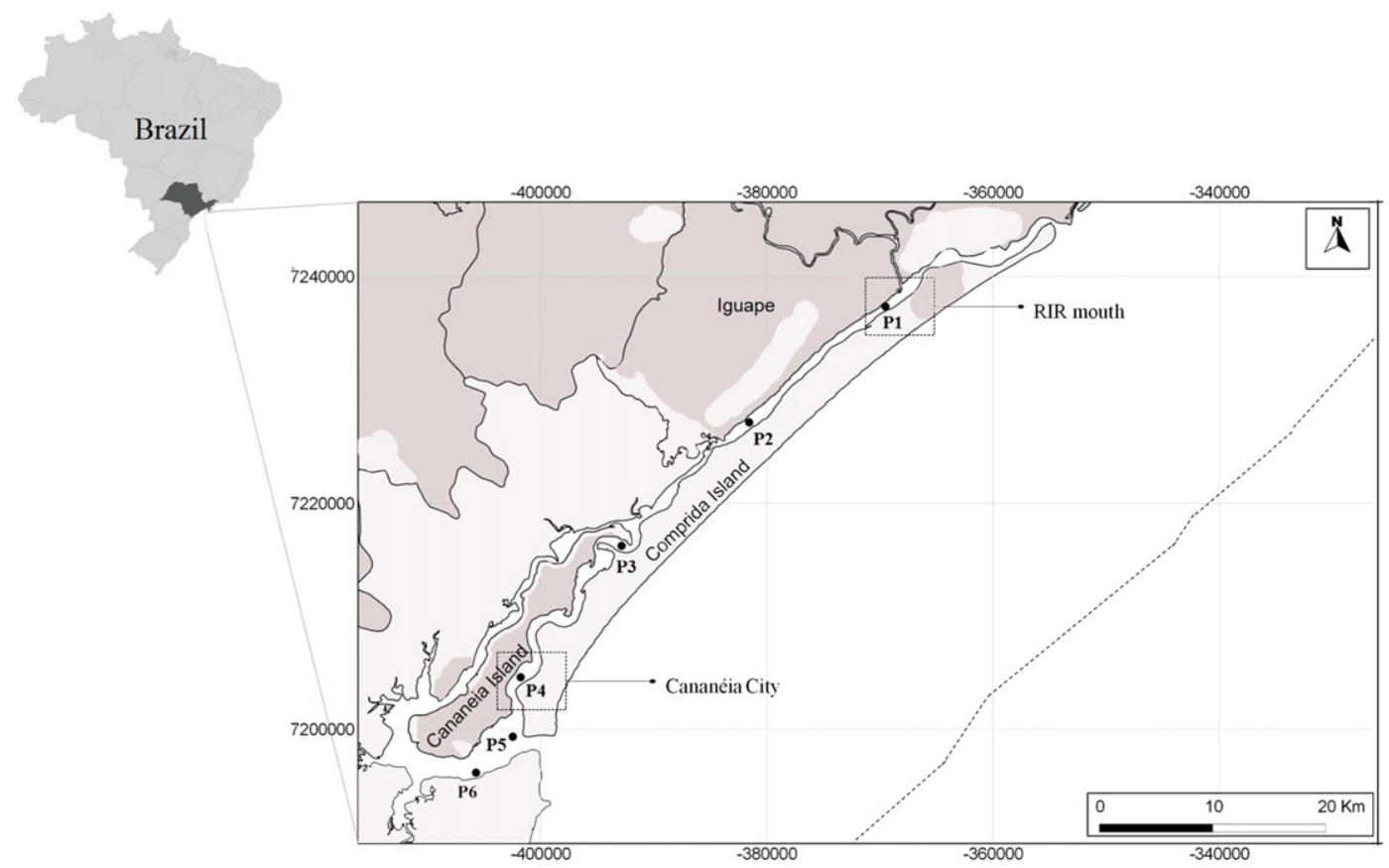

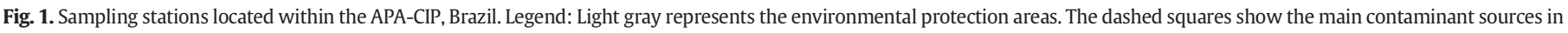
the area, and the dotted lines represent the inner boundary of the MPA.

site using a bottom otter trawl. The study area has well defined seasons, i.e. a dry winter (July to August, monthly average rainfall of $95.3 \mathrm{~mm}$ ) and a rainy summer (January to March, monthly average rainfall of $266.9 \mathrm{~mm}$ ). Monthly mean temperature ranges from a maximum of $28{ }^{\circ} \mathrm{C}$ (February) to a minimum of $20{ }^{\circ} \mathrm{C}$ (July) (Cunha-Lignon et al., 2009). To account for this seasonal variation, two sampling campaigns were conducted: one during the dry season (D) (August 2012), and the other during the rainy season (R) (March 2013). Average rainfall during the sampling campaigns was $111 \mathrm{~mm}$ and $390 \mathrm{~mm}$, respectively (CEPAGRI, 2014).

The collected specimens were kept in local water under aeration until transportation to the laboratory, located in the city of Cananéia. Five animals were set aside for body burden analyses, and ten individuals were set aside for genotoxicity analyses and for bile fluid extraction. Before being euthanized via spinal cord section, individuals were anesthetized with benzocaine $(0.01 \%)$ in water, then weighed and measured. To measure genotoxicity biomarkers, peripheral blood was withdrawn from the caudal vein using heparinized syringes for the comet assay, the micronucleus test, and tests for nuclear alterations. After euthanasia, the gills, kidney, and liver were dissected, frozen, and stored at $-80^{\circ} \mathrm{C}$ for the DNA strand break assessment. Axial muscle and liver used in body burden analyses were stored in plastic vessels at $-20{ }^{\circ} \mathrm{C}$ until the analyses. Bile fluid was stored in glass vessels kept at $-80{ }^{\circ} \mathrm{C}$ for PAH metabolite analyses.

Fulton's condition factor was calculated according to the formula $\mathrm{KF}=(\mathrm{W} / \mathrm{L} 3 \times 100)$, where $\mathrm{KF}=$ Fulton's condition factor, $\mathrm{W}=$ body weight in grams, and $\mathrm{L}=$ total body length in $\mathrm{cm}$.

\subsection{Genotoxicity assessment}

2.3.1. Comet assay, micronucleus test (MN) and nuclear abnormalities test (NA) in peripheral blood

Comet assay followed the procedures described by Singh et al. (1988) and Ferraro et al. (2004). Blood was diluted in fetal bovine serum and stored on ice (protected from light) for $24 \mathrm{~h}$. Microscope slides were prepared with a blood cell suspension $(10 \mu \mathrm{l})$ in low melting point agarose $(120 \mu \mathrm{l})$ at $37^{\circ} \mathrm{C}$, followed by incubation in lysis solution at $4{ }^{\circ} \mathrm{C}$ for 7 days. After lysis incubation, the slides were placed in a $\mathrm{NaOH}$ $(10 \mathrm{M})$ and EDTA $(200 \mathrm{mM})$ solution at a $\mathrm{pH}>13$ for $20 \mathrm{~min}$ for DNA denaturation. Electrophoresis was carried out at $25 \mathrm{~V}$ and $300 \mathrm{~mA}$ for $25 \mathrm{~min}$ at $4{ }^{\circ} \mathrm{C}$, and slides were neutralized for $15 \mathrm{~min}$ with $0.4 \mathrm{M}$ Tris, $\mathrm{pH} 7.5$, fixed in $95 \%$ ethanol for $5 \mathrm{~min}$, and stained with ethidium bromide $\left(0.02 \mu \mathrm{g} \mathrm{ml}^{-1}\right)$. DNA damage was observed using a Leica ${ }^{\circledR}$ epifluorescence microscope at a magnification of $400 \times$. For each fish, 100 nucleoids were visually analyzed according to the method described by Ramsdorf et al. (2009).

The analysis of NA in erythrocytes is a variant of the standard MN test. It includes the quantification of the number of alterations in cell nuclei that may generate micronuclei. These analyses may complement traditional MN scoring (Ayllon and Garcia-Vazquez, 2000; Cavaş and Ergene-Gözükara, 2005; Costa and Costa, 2007; Costa et al., 2008). Nuclear abnormalities may be a consequence of effects caused by clastogenic pollutants, and may lead to problems in chromosomal attachments and/or gene amplification (Omar et al., 2012).

In the current study, blood aliquots were immediately smeared on glass microscopy slides. Before being air-dried, the layer was fixed with absolute ethanol (30 min) and stained with acridine orange. For each animal, 2000 erythrocytes were examined under a Leica ${ }^{\circledR}$ epifluorescence microscope at $1000 \times$ magnification and scored based on the presence of both typical MN and NA. MN tests were performed in accordance with Heddle (1973) and Schmid (1975), while NAs (blebbed, lobed, vacuolated, and notched) were characterized in accordance with Carrasco et al. (1990).

\subsubsection{Alkaline precipitation assay in kidney, liver, and gills}

Kidney, liver, and gill tissues were kept on ice throughout the analyses. The liver and kidneys were analyzed because they are target organs in metabolism and in the accumulation of contaminants (Bernet et al., 1999), whereas gills were chosen because they exhibit high permeability to ions, and are continuously ventilated to allow for the exchange of gases, ions, salts, and water with the environment (Hill et al., 2004).

Tissues were homogenized at $10 \% W / V$ in Tris- $\mathrm{HCl}$ buffer (Tris 50 mM; EDTA 1 mM; DTT 1 mM; Sucrose 50 mM; KCl 150 mM; 
PMSF $1 \mathrm{mM}, \mathrm{pH} 7.6)$. The homogenates were centrifuged at $12,000 \times \mathrm{g}$ for $20 \mathrm{~min}$ at $4{ }^{\circ} \mathrm{C}$, and aliquots of the supernatant were kept for the analysis.

DNA strand breaks were measured using an alkaline precipitation assay (Olive, 1988; Gagne and Blasé, 1995). This assay is based on the potassium-dodecylsulfate precipitation of protein-bound genomic DNA, which leaves protein-free DNA strand breaks in the supernatant. These DNA strands are quantified using fluorescence $(\lambda$ ex $360 \mathrm{~nm}$ and $\lambda$ em $450 \mathrm{~nm}$ ) after being stained with Hoechst dye. Standard solutions of salmon sperm DNA were used for calibration. Protein concentrations were determined spectrophotometrically at $595 \mathrm{~nm}$ (Bradford, 1976), with BSA as the standard. All biomarker analyses were performed in a microplate reader (Biotek-Synergy ${ }^{\mathrm{TM}} \mathrm{HT}$ ). The results were expressed as $\mu \mathrm{g}$ DNA mg prot $^{-1}$.

\subsection{Body burden of metals}

Arsenic (As) concentrations in muscle and liver tissues were calculated using an atomic absorption spectrophotometer (Varian ${ }^{\circledR}, A A$ 240Z) equipped with a graphite furnace (AAS-GF) (Model, GTA 120). Metals were quantified using flame atomic absorption spectroscopy (F-AAS) (Varian ${ }^{\circledR}$, AA 240FS). All analyses were performed according to the standards of METHOD 200.9 (USEPA, 1994). The detection limit for As was $5.88 \mu \mathrm{g} \mathrm{kg}^{-1}$. The detection limits used for the metals were $0.034 \mathrm{mg} \mathrm{kg}^{-1}(\mathrm{Cu}), 0.0697 \mathrm{mg} \mathrm{kg}^{-1}(\mathrm{Mn}), 0.0525 \mathrm{mg} \mathrm{kg}^{-1}$ (Zn), $0.112 \mathrm{mg} \mathrm{kg}^{-1}(\mathrm{Cr}), 0.146 \mathrm{mg} \mathrm{kg}^{-1}(\mathrm{Co}), 0.0623 \mathrm{mg} \mathrm{kg}^{-1}(\mathrm{Ni})$, $0.042 \mathrm{mg} \mathrm{kg}^{-1}(\mathrm{Cd})$, and $0.0602 \mathrm{mg} \mathrm{kg}^{-1}(\mathrm{~Pb})$. The limits of quantification (LOQ) used were $0.178 \mathrm{mg} / \mathrm{kg}^{-1}$ for As, $0.004 \mathrm{mg} / \mathrm{kg}^{-1}$ for $\mathrm{Cu}$, $0.537 \mathrm{mg} / \mathrm{kg}^{-1}$ for $\mathrm{Mn}, 0.720 \mathrm{mg} / \mathrm{kg}^{-1}$ for $\mathrm{Zn}, 0.345 \mathrm{mg} / \mathrm{kg}^{-1}$ for $\mathrm{Cr}$, $0.390 \mathrm{mg} / \mathrm{kg}^{-1}$ for $\mathrm{Co}, 0.204 \mathrm{mg} / \mathrm{kg}^{-1}$ for $\mathrm{Ni}, 0.059 \mathrm{mg} / \mathrm{kg}^{-1}$ for $\mathrm{Cd}$, and $0.545 \mathrm{mg} / \mathrm{kg}^{-1}$ for $\mathrm{Pb}$.

Standard curves were prepared using reference material (Qhemis High Purity ${ }^{\circledR)}$ ). Quality control for analytical procedures was performed using standard addition, and recovery rates ranged from $80 \%$ to $120 \%$ for all of the elements investigated. Metal and As concentrations were expressed as $\mathrm{mg} \mathrm{kg}^{-1}$ of dry weight.

\subsection{PAH metabolites in bile}

PAHs may come from different anthropogenic sources: 2- to 4-ring PAHs are understood to come from petrogenic sources of pollution, while 5- to 6-ring PAHs have been linked to pyrolytic sources (Olajire et al., 2005). The metabolites of polycyclic aromatic hydrocarbons (PAHs) in the bile of $C$. spixii were quantified through the use of fixed wavelength fluorescence in a spectrofluorometer (SunriseTecan) at wavelengths of $288 / 330 \mathrm{~nm}, 334 / 376 \mathrm{~nm}, 364 / 406 \mathrm{~nm}$, and

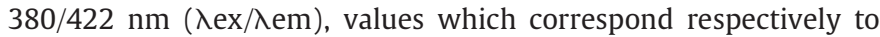
naphthalene-type (2 rings), pyrene-type (4 rings), benzo(a)pyrenetype ( 5 rings), and benzo(ghi)perylene-type (6 rings) (Aas et al., 2000; Oliveira Ribeiro et al., 2005). PAH concentrations were determined through comparisons with a standard curve for each group of rings. The results were expressed as units of PAH mg prot ${ }^{-1}$.

\subsection{Statistical analyses}

First, datasets on specimen length, condition factor, comet scores, MN and NA frequencies in the blood, and DNA strand breaks in kidney, liver, and gill tissues, as well as on total PAH contents in the bile, were all tested for normality (Kolmogorov-Smirnov's test) and for homoscedasticity (Bartlett's method). Datasets that met Analysis of Variance (ANOVA) assumptions were tested for differences between the means with ANOVA, followed by Tukey's post-hoc test. Non-parametric statistical tests (Kruskal-Wallis test with Dunn's multiple comparisons as a post-hoc test) were used to compare data series that violated ANOVA assumptions.
Pearson correlation analysis was performed using the data on the levels of individual PAH metabolites in the bile from each season data matrix in order to assess significant correlations among individual PAHs along the sampling sites. The significance level was set at $\mathrm{p} \leq 0.05$ for all analyses.

\subsubsection{Multivariate approach}

Factor analysis with principal component analysis (FA/PCA) as the extraction procedure was used to highlight the associations between the genotoxic responses (DNA strand breaks in kidney, liver, and gill tissues; comet scores; frequencies of micronuclei, blebbed, lobed, vacuolated and notched nuclei; and total nuclear abnormalities in blood), contaminant body burdens ( $\mathrm{Cu}, \mathrm{Mn}, \mathrm{Zn}, \mathrm{Cr}, \mathrm{Co}, \mathrm{Ni}, \mathrm{Cd}, \mathrm{Pb}$, and $\mathrm{As}$ ), and total metabolites of PAHs in the bile in each season (dry and rainy). The variables were autoscaled (standardized) so as to be given equal importance. Only factors with eigenvalues greater than 1.0 were interpreted (Kaiser criterion). The variables selected for interpretation were those associated with the factors with a loading $\geq 0.60$, a value which is more conservative than the loading cut-off recommended by Tabachnic and Fidell (1996). The relevance of the associations observed with each of the 6 sampling stations (cases) was estimated by calculating the factor score from each case to the centroid of all cases for the original data. All of the analyses were performed using the STATISTICA 12 software (StatSoft Inc., USA).

\section{Results}

\subsection{Condition factor $(K)$}

The length of the specimens collected in the different sampling stations along the APA-CIP during the dry season were quite homogeneous (ranging from $16.4 \mathrm{~cm}$ to $20.5 \mathrm{~cm}$ ) (ANOVA; $\mathrm{p}>0.05$ ) but specimens from $\mathrm{P} 1$ exhibited significantly higher condition factor compared to the other stations (ANOVA; $\mathrm{p} \leq 0.05$ ).

During the rainy season, organisms from P5 showed significantly higher length than those from P1, P2, and P4 (ANOVA; $\mathrm{p} \leq 0.05$ ), however fish from P1 and P2 showed significantly higher condition factor than specimens from P3 and P5 (ANOVA; $\mathrm{p} \leq 0.05$ ).

\subsection{Body burden of metals}

Levels of metals ( $\mathrm{Cu}, \mathrm{Mn}, \mathrm{Zn}, \mathrm{Cr}, \mathrm{Co}, \mathrm{Ni}, \mathrm{Cd}, \mathrm{Pb})$ and $\mathrm{As}$ in liver and muscle tissues of $C$. spixii are shown in Table 1 . During the dry season, metal burdens in muscle and liver tissues were generally higher in the sections of the APA-CIP around the city of Cananéia, whereas during the rainy season, these values were higher in specimens from stations affected by the RIR.

In some instances, levels of $\mathrm{Cd}, \mathrm{Pb}$, and As in the muscle were higher than the levels set by Mercosul and by the Brazilian Sanitary Vigilance Authority (ANVISA); these two institutions established limits of 0.3 , 1.0 , and a range from 0.05 to $0.3 \mathrm{mg} \mathrm{kg}^{-1} \mathrm{~W} . \mathrm{w}$. for Pb, As, and Cd, respectively (ANVISA, 2013). Levels were also higher than those set by the FAO/WHO (2014), which are $2.0 \mathrm{mg} \mathrm{kg}^{-1}$ w.w. for $\mathrm{Pb}$, and $1.0 \mathrm{mg} \mathrm{kg}^{-1}$ w.w. for As and Cd. In addition, the values were higher than those set by the EC - European Commission $(2002,2006)$, in which Cd ranges from 0.1 to $0.30 \mathrm{mg} \mathrm{kg}^{-1}$ w.w. and $\mathrm{Pb}$ is $0.30 \mathrm{mg} \mathrm{kg}^{-1}$ w.w.

\subsection{PAH metabolites in bile}

The levels of PAHs (2-ringed, 4-ringed, and 5-ringed) in the bile (Fig. 2a and b) were significantly correlated with each other $(\mathrm{p} \leq 0.05)$ among the sampling sites during the dry season. Still in the dry season, the concentrations of all analyzed PAHs increased at P3 (although significant differences were detected only for 4- and 5-ringed PAHs), and 4-ringed PAHs were significantly higher at P3 and P4 (ANOVA; $\mathrm{p} \leq 0.05$ ). 
Table 1

Metals ( $\mathrm{mg} \mathrm{kg}^{-1} \mathrm{DW}$ ) and As ( $\mu \mathrm{kg}^{-1} \mathrm{DW}$ ) burdens in muscle and liver in each sampling site (P1 to P6) during the dry (D) and rainy (R) seasons.

\begin{tabular}{|c|c|c|c|c|c|c|c|c|c|c|c|}
\hline \multicolumn{12}{|c|}{ Sampling stations } \\
\hline Variables & P1-D & P3-D & P4-D & P5-D & P6-D & P1-R & P2-R & P3-R & P4-R & P5-R & P6-R \\
\hline Cu mus & 0.10 & 0.10 & 0.10 & 0.10 & 0.10 & 0.10 & 0.10 & 0.10 & 0.10 & 0.10 & 0.10 \\
\hline Mn mus & 2.01 & 0.13 & 3.81 & 0.13 & 0.13 & 3.40 & 0.27 & 0.44 & 0.13 & 0.13 & 0.13 \\
\hline Zn mus & 11.14 & 9.19 & 34.52 & 12.24 & 15.36 & 34.99 & 24.01 & 12.10 & 22.49 & 65.57 & 12.12 \\
\hline $\mathrm{Cr}$ mus & 0.08 & 0.08 & 0.08 & 0.08 & 0.08 & 0.08 & 0.08 & 0.08 & 0.08 & 0.08 & 0.08 \\
\hline Co mus & 0.11 & 0.11 & 0.11 & 273.00 & 180.00 & 114.33 & 98.81 & 98.24 & 242.08 & 122.70 & 100.42 \\
\hline Ni mus & 0.09 & 0.09 & 109.35 & 339.33 & 201.29 & 125.44 & 93.27 & 102.13 & 140.89 & 117.90 & 85.01 \\
\hline $\mathrm{Cd}$ mus & 13.64 & 9.04 & 10.56 & 1.11 & 0.11 & 0.11 & 0.11 & 0.11 & 0.11 & 0.11 & 0.11 \\
\hline $\mathrm{Pb}$ mus & 32.39 & 21.64 & 47.88 & 73.22 & 49.83 & 31.56 & 8.06 & 0.11 & 0.11 & 0.11 & 0.11 \\
\hline As mus & 2.17 & 10.73 & 5725,47 & 21.98 & 149.23 & 2.55 & 4.26 & 2.76 & 7.86 & 3.02 & 9.51 \\
\hline Cu liver & 79.06 & 11.23 & 0.10 & 22.24 & 88.93 & 10.82 & 25.49 & 43.77 & 146.70 & 10.78 & 17.37 \\
\hline Mn liver & 0.13 & 0.13 & 0.13 & 0.13 & 0.13 & 0.13 & 4.33 & 2.15 & 0.13 & 4.09 & 5.80 \\
\hline Zn liver & 123.93 & 146.82 & 143.59 & 201.47 & 259.69 & 347.42 & 381.07 & 306.71 & 110.89 & 122.57 & 537.84 \\
\hline Cr liver & 5.72 & 6.08 & 22.91 & 39.28 & 16.22 & 14.90 & 6.90 & 0.08 & 0.08 & 0.08 & 0.08 \\
\hline Co liver & 2.59 & 13.47 & 160.00 & 333.59 & 140.81 & 229.00 & 135.26 & 233.52 & 250.00 & 43.41 & 23.69 \\
\hline Ni liver & 0.09 & 0.09 & 0.09 & 0.09 & 0.09 & 0.09 & 0.09 & 0.09 & 0.09 & 0.09 & 0.09 \\
\hline Cd liver & 0.11 & 0.11 & 0.11 & 0.11 & 0.11 & 0.11 & 0.11 & 0.11 & 1.18 & 0.11 & 1.58 \\
\hline $\mathrm{Pb}$ liver & 2.13 & 0.11 & 0.11 & 0.11 & 0.11 & 6.39 & 0.11 & 0.11 & 0.11 & 0.11 & 0.11 \\
\hline As liver & 2.78 & 1.23 & 1.51 & 2.18 & 1.85 & 0.85 & 1.79 & 1.11 & 7.35 & 2.55 & 2.20 \\
\hline
\end{tabular}

In the rainy season, only 5-ringed and 6-ringed PAHs were significantly correlated $(\mathrm{p} \leq 0.05)$. 2-ringed PAHs showed the highest value at P4 (ANOVA; $\mathrm{p} \leq 0.05$ ), and 4- and 5-ringed are significantly higher at $\mathrm{P} 1$ and $\mathrm{P} 6$ (ANOVA; $\mathrm{p} \leq 0.05)$.
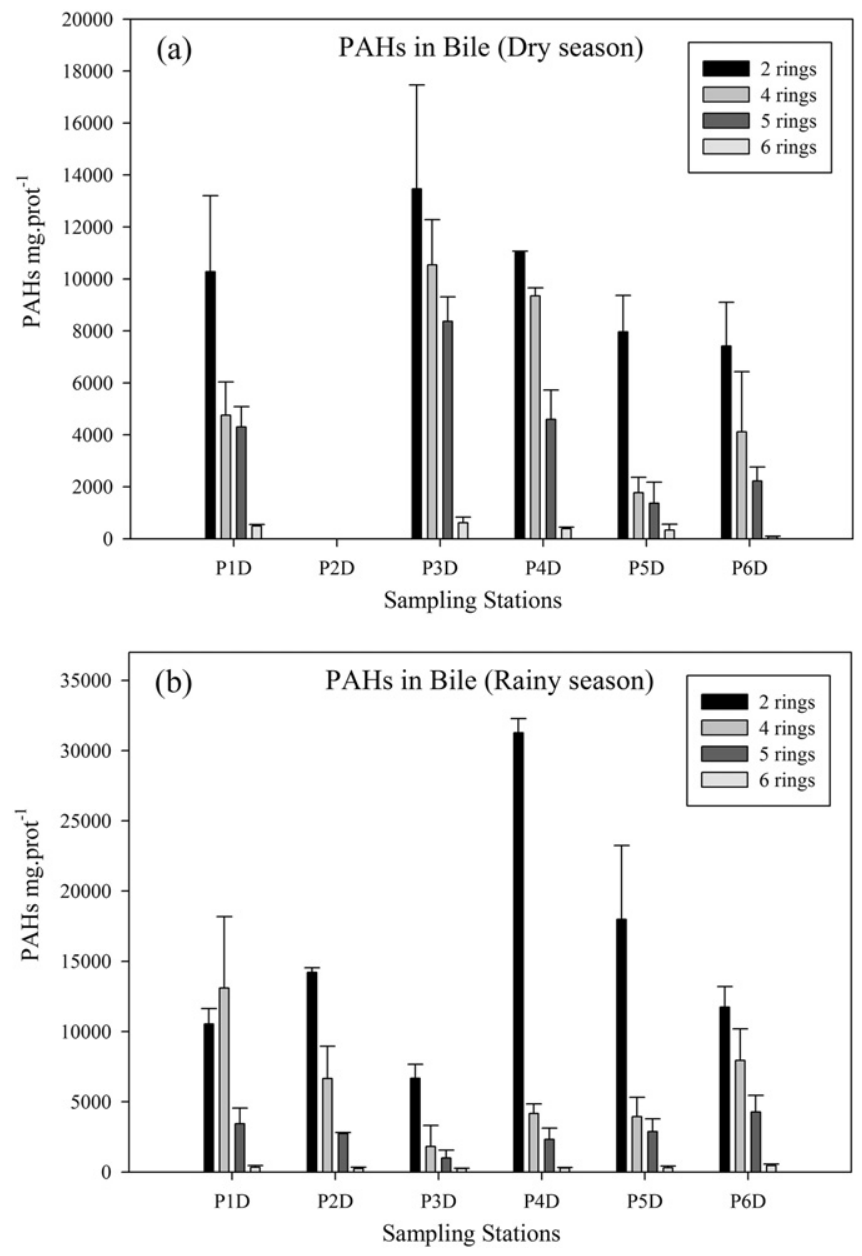

Fig. 2. a and 2b: PAH in bile of Cathorops spixii sampled from the APA-CIP during the dry season (D) and during the rainy season (R). Legend: Site with a line instead of a bar means that no organisms were sampled.

\subsection{Genotoxic responses}

Comet scores (Fig. 3a) showed significant differences only during the dry season, P5 and P6 being the highest scores (ANOVA; $\mathrm{p} \leq 0.05$ ). Regarding the frequency of micronuclei, organisms from site P1 showed significantly higher values compared to the those from some other sites $(\mathrm{P} 3, \mathrm{P} 5, \mathrm{P} 6)$ during both the dry and the rainy season $(\mathrm{KW} ; \mathrm{p} \leq 0.05)$ (Table 2). The highest frequencies of blebbed, notched, and total nuclear abnormalities during both seasons were all recorded for site P5 (Table 2), though the means did not differ significantly among the sites studied (KW; $\mathrm{p}>0.05$ ).

Like comet score values, the DNA strand break results in liver tissue were significantly higher at P5 and P6 only during the dry season (KW; $\mathrm{p} \leq 0.05$ ) (Fig. 3b). DNA damage in kidney tissues was higher at P1, P3, and $\mathrm{P} 5$ during the dry season, and at $\mathrm{P} 1$ and $\mathrm{P} 3$ during the rainy season (Fig. 3c) (KW; p $\leq 0.05)$. In the gills, DNA strand break levels were higher at P1 and P6 during the dry season (Fig. 3d); during the rainy season, P3, $\mathrm{P} 4$ and $\mathrm{P} 5$ presented higher values $(\mathrm{KW} ; \mathrm{p} \leq 0.05)$ with a clear increasing trend from P1 to P5.

\subsection{Multivariate approach}

Two different datasets were used to perform the FA/PCA: (i) one for the dry season data and (ii) the other for the rainy season data. The total explained variance of each FA/PCA was $84 \%$ for the dry season data and $86.41 \%$ for the rainy season data.

The data from the dry season yielded three new variables, or factors (Table 3). Factor 1 (F1) (which explained $44.76 \%$ of the variance) showed an association among DNA damage in blood (comet scores), blebbed and notched nuclei, and body burdens of metal in muscle tissue ( $\mathrm{Co}, \mathrm{Ni}$, and $\mathrm{Pb}$ ) and in liver tissue ( $\mathrm{Co}, \mathrm{Cr}$, and $\mathrm{Zn}$ ). In the score analysis, these associations were found to be highly relevant at sites under the influence of the urban area, particularly in the case of P5 (Table 4). Another group of variables from F1 included micronucleus induction, some metals ( $\mathrm{Cd}$ in the muscle and $\mathrm{Pb}$ in the liver), and all analyzed PAHs in the bile (Table 3). These associations were reflected in the higher scores at P1 and P3 (Table 4). Meanwhile, F2 (22.11\% of explained variance) was associated with genotoxicity (DNA strand breaks in liver and gills, and frequency of vacuolated nuclei) and with As and metals ( $\mathrm{Cu}$ and $\mathrm{Pb}$ ) in the liver (Table 3 ). These associations were seen with progressively higher scores at three of the sites $(\mathrm{P} 1>\mathrm{P} 6>\mathrm{P} 5)$ (Table 4). Another group associated with F2 was that of As and metals in muscle (Mn and $\mathrm{Zn}$ ), 2- and 4-ringed PAHs, but with no relationship to genotoxicity. F3 
(a)

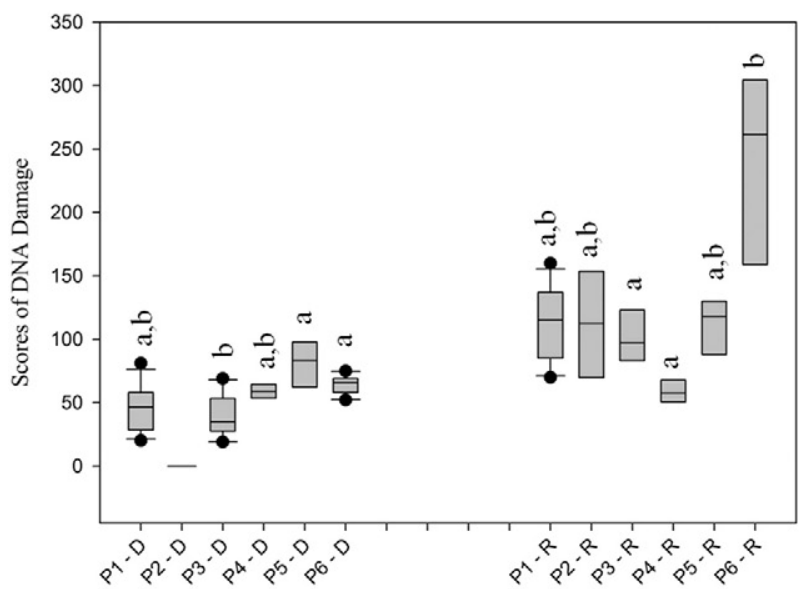

Sampling Stations

(c)

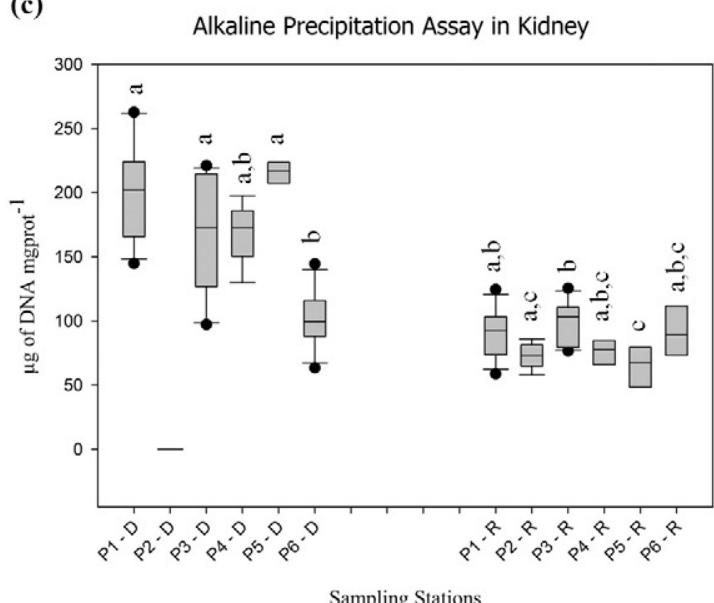

(b) Alkaline Precipitation Assay in Liver

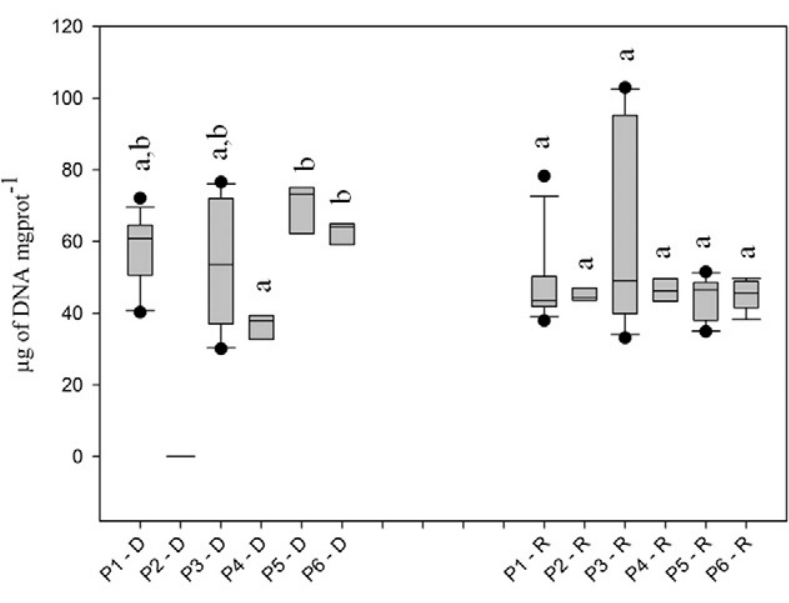

Sampling Stations

(d) Alkaline Precipitation Assay in Gills

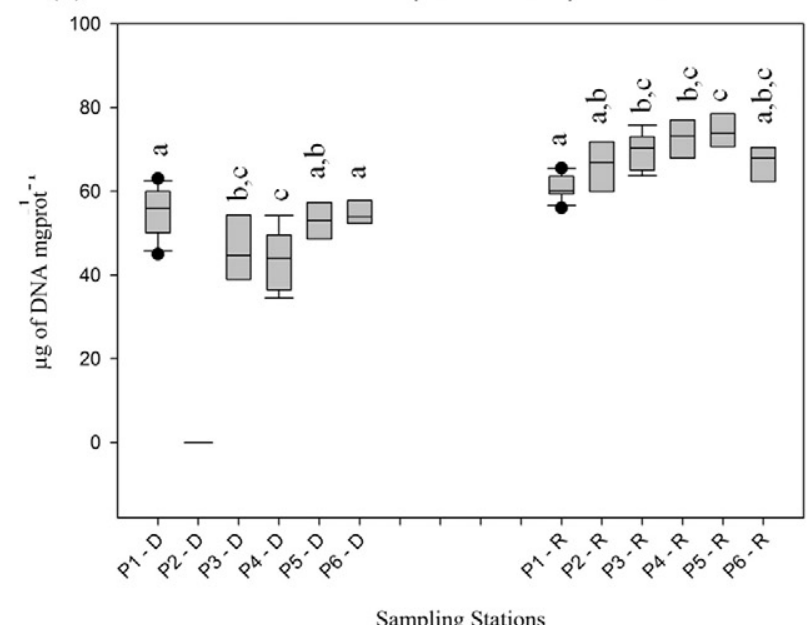

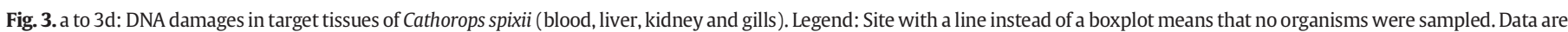

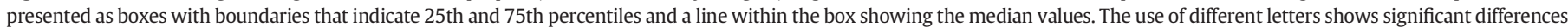
during the same season $(\mathrm{p} \leq 0.05)$.

(18.24\% of explained variance) was found to be linked both to genotoxicity results (DNA damage in kidneys, in addition to notched, blebbed, and total nuclear abnormalities) and to $\mathrm{Cr}$ levels in the liver. This association was particularly relevant at P1, followed by P5. Another group of variables from F3 included the frequency of vacuolated nuclei associated with metals in the liver $(\mathrm{Zn}$ and $\mathrm{Cr}$ ); the highest score was recorded at P6.

The FA/PCA applied to the rainy season data matrix rearranged the data into three new variables (Table 3). F1 (which explained $38.4 \%$ of the variance in the original dataset) found genotoxicity responses

Table 2

Frequency of micronucleated cells and nuclear abnormalities in Cathorops spixii sampled in the APA-CIP, during the dry and rainy seasons. TNA means total nuclear abnormalities.

\begin{tabular}{|c|c|c|c|c|c|c|}
\hline & Micronuclei & Blebbed & Lobed & Vacuolated & Notched & TNA \\
\hline \multicolumn{7}{|c|}{ Dry season } \\
\hline P1-D & $1.92 \pm 2.10$ & $5.85 \pm 3.58$ & $0.08 \pm 0.28$ & $2.23 \pm 2.95$ & $7.77 \pm 3.59$ & $17.85 \pm 8.06$ \\
\hline P3-D & $0.00 \pm 0.00$ & $6.53 \pm 5.36$ & $0.07 \pm 0.26$ & $1.13 \pm 1.73$ & $4.93 \pm 2.22$ & $12.67 \pm 6.52$ \\
\hline P4-D & $1.20 \pm 1.87$ & $5.80 \pm 4.83$ & $0.00 \pm 0.00$ & $2.50 \pm 5.87$ & $7.00 \pm 5.42$ & $16.50 \pm 9.62$ \\
\hline P5-D & $0.13 \pm 0.35$ & $17.25 \pm 17.04$ & $0.00 \pm 0.00$ & $1.88 \pm 2.70$ & $13.63 \pm 8.63$ & $32.88 \pm 24.77$ \\
\hline P6-D & $0.14 \pm 0,36$ & $5.21 \pm 5.37$ & $0.00 \pm 0.00$ & $2.07 \pm 1.94$ & $7.00 \pm 6.37$ & $14.64 \pm 12.29$ \\
\hline \multicolumn{7}{|c|}{ Rainy season } \\
\hline P1-R & $0.93 \pm 1.16$ & $14.80 \pm 15.69$ & $0.00 \pm 0.00$ & $3.80 \pm 5.65$ & $28.73 \pm 12.38$ & $48.27 \pm 19.52$ \\
\hline P2-R & $0.60 \pm 0.70$ & $21.00 \pm 16.08$ & $0.00 \pm 0.00$ & $2.10 \pm 3.21$ & $18.30 \pm 5.74$ & $42.00 \pm 14.82$ \\
\hline P3-R & $0.09 \pm 0.30$ & $21.00 \pm 15.85$ & $0.00 \pm 0.00$ & $1.55 \pm 2.25$ & $19.64 \pm 11.28$ & $42.27 \pm 23.07$ \\
\hline P4-R & $0.00 \pm 0.00$ & $22.00 \pm 7.57$ & $0.00 \pm 0.00$ & $0.57 \pm 0.79$ & $14.71 \pm 4.99$ & $37.29 \pm 11.16$ \\
\hline P5-R & $0.00 \pm 0.00$ & $32.10 \pm 35.42$ & $0.00 \pm 0.00$ & $1.80 \pm 5.03$ & $22.50 \pm 18.49$ & $56.40 \pm 12.08$ \\
\hline P6-R & $0.14 \pm 0.37$ & $27.71 \pm 13.05$ & $0.00 \pm 0.00$ & $0.86 \pm 1.86$ & $14.86 \pm 9.17$ & $43.57 \pm 15.67$ \\
\hline
\end{tabular}


Table 3

Summary of factor loadings (after Varimax rotation) of the FA-PCA applied on the data matrices of dry season (only loadings $>0.44$ are showed) and rainy season (only loadings $>0.50$ are showed). The variances of the principal factors are given in percentage of the total variance in the original data matrices.

\begin{tabular}{|c|c|c|c|c|c|c|}
\hline \multirow[b]{2}{*}{ Factors } & \multicolumn{3}{|c|}{ Dry season } & \multicolumn{3}{|c|}{ Rainy season } \\
\hline & $\mathrm{F} 1$ & $\mathrm{~F} 2$ & F3 & $\mathrm{F} 1$ & F2 & F3 \\
\hline Variance & $44.70 \%$ & $22.12 \%$ & $18.24 \%$ & $38.40 \%$ & $27.70 \%$ & $16.82 \%$ \\
\hline Mn muscle & - & -0.50 & - & -0.95 & - & - \\
\hline Zn muscle & - & -0.74 & - & - & - & - \\
\hline Co muscle & 0.91 & - & - & - & -0.98 & - \\
\hline Ni muscle & 0.97 & - & - & - & -0.79 & - \\
\hline Cd muscle & -0.91 & - & - & - & - & - \\
\hline $\mathrm{Pb}$ muscle & 0.90 & - & - & -0.99 & - & - \\
\hline As muscle & - & -0.78 & - & - & - & -0.83 \\
\hline Cu liver & - & 0.84 & -0.49 & - & -0.91 & - \\
\hline Mn liver & - & - & - & - & 0.64 & -0.51 \\
\hline Zn liver & 0.82 & - & -0.48 & - & 0.60 & -0.60 \\
\hline Cr liver & 0.85 & - & 0.48 & -0.97 & - & - \\
\hline Co liver & 0.91 & - & - & - & -0.51 & 0.58 \\
\hline Cd liver & - & - & - & - & -0.97 & - \\
\hline As liver & - & 0.79 & - & - & -0.92 & - \\
\hline $\mathrm{Pb}$ liver & -0.63 & 0.62 & - & -0.95 & - & - \\
\hline PAHs (2 rings) & -0.61 & -0.75 & - & - & -0.94 & - \\
\hline PAHs (4 rings) & -0.58 & -0.78 & - & -0.85 & - & - \\
\hline PAHs (5 rings) & -0.82 & - & - & - & - & -0.85 \\
\hline PAHS (6 rings) & -0.77 & - & - & - & - & -0.87 \\
\hline Total nuclear abnormalities & - & - & 0.90 & - & -0.50 & - \\
\hline Micronuclei & -0.64 & - & & -0.96 & - & - \\
\hline Blebbed nuclei & 0.44 & - & 0.73 & 0.51 & - & -0.82 \\
\hline Vacuolated nuclei & - & 0.59 & -0.57 & -0.57 & - & 0.50 \\
\hline Notched nuclei & 0.54 & - & 0.83 & -0.96 & - & - \\
\hline DNA damage in kidney & - & - & 0.98 & - & - & - \\
\hline DNA damage in liver & - & 0.79 & - & - & - & 0.68 \\
\hline DNA damage in gills & - & 0.98 & - & 0.90 & - & - \\
\hline DNA damage in blood & 0.92 & - & - & - & 0.55 & -0.80 \\
\hline
\end{tabular}

(frequencies of micronuclei, notched nuclei, and vacuolated nuclei) to be associated with 4-ring PAHs in the bile and with bioaccumulated metals ( $\mathrm{Mn}$ and $\mathrm{Pb}$ in muscle tissue and $\mathrm{Cu}$ and $\mathrm{Pb}$ in liver tissue) (Table 3). The estimated scores for this factor were higher at the sites affected by the Ribeira do Iguape River (particularly P1) (Table 4). F2 (27.7\% of explained variance) was found to be associated with DNA damage in blood cells and bioaccumulated $\mathrm{Zn}$ and $\mathrm{Mg}$ in liver tissue. These associations occurred with a high score at P6. Other associations with F2 included total nuclear abnormalities, accumulated $\mathrm{As}, \mathrm{Cd}, \mathrm{Cu}$, and $\mathrm{Co}$ in the liver, and $\mathrm{Co}$ and $\mathrm{Ni}$ in muscle tissue, including 2-ring PAHs. This factor was relevant only at P4. F3 (16.8\%) revealed an association among genotoxicity (DNA damage to erythrocytes and blebbed nuclei frequency), PAHs in the bile (5- and 6-rings), As contents in

Table 4

Factor scores estimated for each of the sampling stations in dry (D) and rainy (R) seasons evaluated in the APA-CIP to the centroid of all cases for the original data.

\begin{tabular}{lrrr}
\hline Station & F1 & \multicolumn{2}{l}{ F2 } \\
\hline Dry season & & & F3 \\
P1-D & -1.12 & 1.10 & 0.33 \\
P3-D & -0.83 & -0.48 & -0.08 \\
P4-D & -0.03 & -1.47 & -0.03 \\
P5-D & 1.18 & 0.29 & 1.28 \\
P6-D & 0.81 & 0.55 & -1.50 \\
Rainy season & & & \\
P1-R & & 0.05 & 0.18 \\
P2-R & -1.93 & 0.31 & -0.05 \\
P3-R & -0.16 & 0.67 & 1.25 \\
P4-R & 0.52 & -1.99 & -0.04 \\
P5-R & 0.37 & 0.35 & 0.46 \\
P6-R & 0.82 & 0.61 & -1.79 \\
\hline
\end{tabular}

muscle tissue, and $\mathrm{Mn}$ and $\mathrm{Zn}$ in liver tissue (Table 3). These relationships were strongly relevant at P6 (Table 4).

\section{Discussion}

The results of the current study suggest that contaminants from land-based activities - in this case, a former mining area and urban sewage discharge - tend to cause genotoxic effects on fish from the APA-CIP. The FA/PCA demonstrated that relationships between bioaccumulated metals (mainly $\mathrm{Cr}, \mathrm{Zn}, \mathrm{Co}, \mathrm{Pb}$ and $\mathrm{Cu}$ ) and genotoxic effects were repeatedly found during both the dry season and the rainy season.

$\mathrm{Cr}$ was the metal that was most frequently associated with genotoxicity in the current study. Previous studies corroborate the genotoxicity of $\mathrm{Cr}$ by reporting the occurrence of genotoxic effects in different fish species exposed to $\mathrm{K}_{2} \mathrm{Cr}_{2} \mathrm{O}_{7}$ (Ahmed et al., 2013), $\mathrm{Cr}$ (VI) (Al-Sabti et al., 1994; Li et al., 2011), Cr (III) (Al-Sabti et al., 1994), as well as to water from a chromium-containing tannery effluent discharge site (Matsumoto et al., 2006).

Although a previous investigation showed that $\mathrm{Cr}$ is not related with mining operations in the APA-CIP (Mahiques et al., 2009), other metals potentially related to old mining activities in the area (e.g. $\mathrm{Zn}, \mathrm{Co}, \mathrm{Cu}$, $\mathrm{Pb}$ ) also showed association between body burdens (especially in liver tissue) and genotoxic responses. $\mathrm{Pb}$ in muscle was also frequently linked to genotoxicity in the current study. Previous studies reported genotoxic effects on Hoplias malabaricus (Ramsdorf et al., 2009) and Prochilodus lineatus (Monteiro et al., 2011) in response to inorganic Pb ( $\mathrm{Pb}$ II) exposure. This metal has also been associated with lethality in fish, as well as with decreased reproductive performance, growth inhibition, and changes in behavior under sub-lethal exposure (Burdena et al., 1998).

As showed by previous studies, $\mathrm{Cu}$ has also been linked to increased genotoxicity in both saltwater and freshwater fish (Gabbianelli et al., 2003; Harabawy and Mosleh, 2014). In the case of Zn, although many studies have shown that its accumulation is a direct function of environmental levels (refer to Hogstrand, 2012 for a review), the existence of strong mechanisms of limiting internal $\mathrm{Zn}$ variation in fish was also previously suggested, since this is an essential metal (McGeer et al., 2003; Orieux et al., 2011). In the literature, the association of genotoxicity with $\mathrm{Zn}$ is not as evident as with other metals, but other toxicity responses have been reported, such as modification in hematological parameters and disturbances in specific and non-specific immune mechanisms of fishes (Witeska and Ko, 2003).

The multivariate analyses performed in the current study were able to show that MN and NA were more frequently associated with bioaccumulated metals than the other genotoxic responses (such as DNA strand breaks). This difference can be partially explained by the fact that DNA strand breaks reflect damage at the molecular level, while MN/NA analyses quantify damage at the chromosomal level (Wirzinger et al., 2007). At the molecular level, DNA damage assays (comet assay or alkaline precipitation) detect alkali-labile sites or DNA lesions that are repairable; on the other hand, the analyses at the chromosomal level (MN and NA) detect fixed mutations that are persistent for at least one mitotic cycle (Kassie et al., 2000). Therefore, the induction of MN and NA from cell injury and mitotic errors may be a result of not-repaired DNA damage, and it may also be accompanied by cell death via apoptosis and necrosis (Omar et al., 2012). Although the MN levels observed in the current study were low, the genotoxic responses at the chromosomal level tend to be more closely associated with contamination exposure than the molecular-level responses. These results suggest that the assessment at chromosomal level is less vulnerable to the natural environmental variations in estuaries. This is important for the environmental assessment or monitoring of MPAs, since differentiating the effects of contamination from the effects of the natural environmental tends to be more difficult in areas showing moderate levels of contamination. 
Furthermore, the MN results indicate that some chromosome responses may also be linked to seasonal differences, e.g. water temperature. As shown in Table 2, MN cell frequencies at the different sampling sites were higher during the dry season (which corresponds to the austral winter and the lowest water temperatures of the year) than during the rainy season (austral summer). This difference suggests that the mechanism of chromosome repair may be more effective during the rainy season, when water temperature is higher (a situation which also increases fishes' metabolism). Previous studies showed the role of low temperature in DNA damage. This is likely to occur because protein synthesis decreases as a result of low RNA translation rates (Benincá et al., 2012; Pellacani et al., 2006; Buschini et al., 2003). Thus, DNA repair mechanisms may be slower and less efficient, and can lead eventually to genetic damage (Pellacani et al., 2006; Buschini et al., 2003). Although these studies show evidences of mechanisms for genetic material repair only at the molecular level, our results suggest that the repair mechanisms may act at the chromosomal level as well. The use of genotoxicity responses for the environmental assessment of MPAs must take into account seasonal variations on mechanisms of DNA and chromosome repair.

Another factor that can influence the differences observed in the bioaccumulated metals is the use of different tissues for the analyses. The genotoxic responses assessed in peripheral blood were more frequently associated with body burdens of metals than they were with the responses in kidney, liver, and gill tissues. Variations in the damage to genetic material is expected in different tissues because of the differential background levels of DNA single-strand breaks in tissues with different amounts of excision repair, and also because of different metabolism levels and concentrations of antioxidants (Lee and Steinert, 2003; Ali et al., 2008). The higher responsiveness of blood tissue to contaminants was explained due to the greater lifespan of circulating erythrocytes in comparison to cells in kidney, liver, and gill tissues (Ramsdorf et al., 2009).

The FA/PCA results show that, during the dry season, fish from the sites located closer to the mouth of the RIR (P1 and P3) were found to have increased levels of PAHs in the bile, of $\mathrm{Pb}$ in liver, and of $\mathrm{Cd}$ in muscle tissue, all of which were associated with a higher frequency of micronuclei. The site closest to the mouth of the RIR (P1) was also found to have increased levels of $\mathrm{As}, \mathrm{Cu}$, and $\mathrm{Pb}$ in the liver, in addition to vacuolated nuclei and greater DNA damage in the liver and gills. During the rainy season, P1 specimens were again found to have increased $\mathrm{Pb}$ levels in both the liver and muscle tissues. This increase was associated with other metals ( $\mathrm{Mn}$ in muscle tissues and $\mathrm{Cr}$ in the liver), as well as with 4-ring PAH, micronuclei, vacuolated nuclei, notched nuclei, and DNA damage in the gills. It is important to note that salinity is an important controlling factor for the bioavailability of contaminants in estuaries (Chapman and Wang, 2001). It is known that the mixing of freshwater with marine water may decrease the bioavailability of contaminants due to processes of coagulation, precipitation and flocculation (Chapman and Wang, 2001). Therefore, besides the higher input of contaminants in areas closer to the river (Mahiques et al., 2009), the low-salinity environment may also increase the bioavailability of contaminants.

The results suggest that $C$. spixii from the sites under the influence of the RIR were affected by the continuous input of bioavailable metals from the RIR basin. Previous studies found high levels of $\mathrm{Pb}, \mathrm{Cu}, \mathrm{Zn}$, and $\mathrm{Cr}$ in suspended sediments of the RIR (Guimarães and Sígolo, 2008) and this has been attributed to the presence of mining waste from former mining activities in the area. Mahiques et al. (2009) found that the levels of metals $(\mathrm{Pb}, \mathrm{Cu}, \mathrm{Zn}$, and $\mathrm{Cr}$ ) in the APA-CIP increased significantly after the RIR was deviated into the estuary through the Valo Grande Channel.

Although the input from the RIR, the levels of metals in the sediments of the APA-CIP have been found to be moderate (Mahiques et al., 2009). However, the current study found that these metals may be available to demersal fishes such as the $C$. spixii, and that they can be the cause of the observed genotoxicity. The bioavailability of metals to $C$. spixii is consistent with a previous study that reported on the levels of $\mathrm{Pb}, \mathrm{Cd}, \mathrm{Hg}, \mathrm{Cu}$, and $\mathrm{Zn}$ in the muscle tissue of $C$. spixii from the APACIP: levels were found to be equivalent to levels present in specimens from a highly polluted estuary in Brazil (Santos, São Paulo State) (Azevedo et al., 2012). The demersal behavior and benthic foraging habits of this species may contribute to their exposure to the contaminated sediment, which, even at moderate levels, affects the health of these fishes and potentially impacts other benthic species.

The relevance of associations among body burdens of metals and As, levels of PAH metabolites and genotoxicity responses in catfish from sites closer to the city of Cananéia suggest that, besides the former mining activities, urban activities are also an important source of toxic metal and PAH pollution in the APA-CIP. The current findings corroborate previous studies in this area, which linked the presence of contaminants of the urban runoff from the city of Cananéia with toxicity (Cruz et al., 2014) and biomarker responses (Gusso-Choueri et al., 2015).

Metals seem to be the main class of contaminants to be linked to genotoxicity in the APA-CIP, though PAHs in bile have also been associated with genotoxicity at the chromosomal level (MN and NA) and even with DNA damage in gill tissues in areas impacted by the RIR. The higher correlation among the PAH metabolites in the bile found during the dry season indicates that these compounds have the same source of pollution in this season. The results also suggest that the pollution source originates in urban activities, since there is a slight increase in PAHs in bile of $C$. spixii from areas closer to the city (Fig. 2a). Data on PAHs in the bile during the rainy season is not as correlated as the dry-season data, a difference which indicates that the input of individual PAHs differs within the APA-CIP. This is clearly demonstrated in Fig. 2b, where a substantial increase in 2-ringed PAHs (usually associated with petrogenic sources) was found at $\mathrm{P} 4$, which is the site closest to the city of Cananéia. PAH sources in the area impacted by urban activities also include nautical structures (marinas, decks, nautical garages, and small docks), ferry boat stations, nautical gas stations, and urban drainage (Cruz et al., 2014).

In the current study, 4-ringed PAH metabolites in the bile (linked to pyrolytic sources) were the most highly correlated with genotoxicity, especially during the rainy season. Closer to the city of Cananéia, 2-ringed PAHs were also linked to total nuclear abnormalities, again during the rainy season. It is well known that PAHs are associated with strong mutagenicity and carcinogenicity (Myers et al., 2003; Cavaş and Ergene-Gözükara, 2005; Ergene et al., 2007; Costa et al., 2008). These events include mechanisms of chromosomal breakage (leading to the formation of MN and other NA), but they are still not fully understood (Costa et al., 2008).

The aforementioned associations among bioaccumulated As, metals, PAH levels in bile, and genetic biomarkers (DNA breakage, micronuclei frequency and other nuclear abnormalities) in C. spixii provide evidence that these contaminants, even in a moderately contaminated area, have genotoxic effects and may affect the health of fishes (in this case, in the APA-CIP). Genotoxicity responses in C. spixii were suitable for identifying sources of pollution. Additionally, the use of different organs was very important for detecting environmental risk of exposure among the local biota in terms of genotoxicity and complex mixtures of contaminants in the environment.

\section{Conclusions}

The combined use of univariate statistical methods and the multivariate approach allowed the identification differences in the responsiveness of genotoxicity analyses in different tissues to bioaccumulation of As, metals, and exposure to PAHs. The current results indicated that the peripheral blood tissue and genotoxicity response at chromosomal level respond better to contaminants body burdens. This is relevant information to subsidize environmental monitoring and assessment programs in MPAs. 
The multivariate approach also showed that, although previous studies reported moderate metal contamination of APA-CIP sediments, the metals and As are bioavailable and causing genotoxicity in catfish. The results suggest that the main sources of bioavailable metals to the APA-CIP are the Ribeira de Iguape River (RIR) and the city of Cananéia. PAHs can also be a contributor to the genotoxicity responses found in C. spixii from the sites around the city of Cananéia.

\section{Acknowledgments}

The authors thank the Brazilian National Council for Scientific and Technological Development (CNPq; grant \#479899/2013-4), the São Paulo Research Foundation (FAPESP, grant \#2009/52762-6) and the Brazilian Aquatic Research Foundation (FUNDESPA), for the financial support of this project. Dr. Paloma Gusso-Choueri thanks the Brazilian Commission for the Improvement of Higher Education Personnel in Brazil (CAPES) for granting her Ph.D. scholarship. Dr. Abessa thanks CNPq (grants 308649/2011-7 and 311609/2014-7). The authors are also grateful to the Oceanographic Institute of the University of São Paulo (IO/USP) for providing logistic and personnel support for the field work in Cananéia. The authors declare that they have no conflict of interest.

\section{References}

Aas, A., Beyer, J., Goksoyr, A., 2000. Fixed wavelength fluorescence (FF) of bile as a monitoring tool for polyaromatic hydrocarbon exposure in fish: an evaluation of compound specificity, inner filter effect and signal interpretation. Biomarkers 5, 9-23. http://dx.doi.org/10.1080/135475000230505.

Abessa, D.M.S., Gonçalves, L., Perina, F.C., et al., 2014. Sediment geochemistry and climatic influences in a river influenced by former mining activities : the case of Ribeira de Iguape River, SP-PR, Brazil. Open J. Wat. Pollut. Treat. 1 (1), 43-54.

Adams, S.M., Greeley, M.S., 2000. Ecotoxicological indicators of water quality: using multiresponse indicators to assess the health of aquatic ecosystems. Water Air Soil Pollut $123,103-115$

Ahmed, M.K., Kundu, G.K., Al-Mamun, M.H., Sarkar, S.K., Akter, M.S., Khan, M.S., 2013b. Chromium (VI) induced acute toxicity and genotoxicity in freshwater stinging catfish, Heteropneustes fossilis. Ecotoxicol. Environ. Saf . 92, 64-70. http://dx.doi.org/10.1016/ j.ecoenv.2013.02.008.

Ali, D., Nagpure, N.S., Kumar, S., Kumar, R., Kushwaha, B., 2008. Genotoxicity assessment of acute exposure of chlorpyrifos to freshwater fish Channa punctatus (Bloch) using micronucleus assay and alkaline single-cell gel electrophoresis. Chemosphere 71 , 1823-1831. http://dx.doi.org/10.1016/j.chemosphere.2008.02.007.

Al-sabti, K., Metcalfe, C.D., 1995. Fish micronuclei for assessing genotoxicity in water. Mutat. Res. 343, 121-135.

Al-Sabti, K., Franko, M., Andrijanic, B., Knez, S., Stegnar, P., 1994. Chromium-induced micronuclei in fish. J. Appl. Toxicol. 14, 333-336.

Álvarez-León, R., Rey-Carrasco, I., 2003. Fauna extraída en la exploración del barco M/N "Vikheim" al noroeste del Caribe colombiano. Rev. Biol. Trop. 51, 551-553.

ANVISA- Agência Nacional de Vigilância Sanitária (National Health Surveillance Agency), 2013H. Alimentos. Portaria ${ }^{\circ}{ }^{685}$, de 27 de agosto de $1998\left(^{*}\right)$. Parcialmente revogada pela Resolução-RDC n. 42, de 29/08/2013. Available from http://portal.anvisa.gov.br/ wps/portal/anvisa/anvisa/home/alimentos/!ut/p/c4/04_SB8K8xLLM9MSSzPy8xBz9C P0os3hnd0cPE3MfAwMDMydnA093Uz8z00B_A3cvA_2CbEdFADQgSKI!/?1dmy\&urile $=\mathrm{wcm} \% 3 \mathrm{Apath} \% 3 \mathrm{~A} / \mathrm{anvisa}+\mathrm{portal} /$ anvisa/inicio/alimentos/publicacao+alimentos/ contaminantes.

Araujo, G.S., Moreira, L.B., Morais, R.D., et al., 2013. Ecotoxicological assessment of sediments from an urban marine protected area (Xixová-Japuí State Park, SP, Brazil). Mar. Pollut. Bull. 75, 62-68. http://dx.doi.org/10.1016/j.marpolbul.2013.08.005.

Ayllon, F., Garcia-Vazquez, E., 2000. Induction of micronuclei and other nuclear abnormalities in European minnow Phoxinus phoxinus and mollie Poecilia latipinna: an assessment of the fish micronucleus test. Mutat. Res. 467, 177-186. http://dx.doi.org/10. 1016/S1383-5718(00)00033-4

Azevedo, M.C.C., Araújo, F.G., Cruz-Filho, A.G., Gomes, I.D., Pessanha, A.L.M., 1999 Variação espacial e temporal de bagres marinhos (Siluriformes, Ariidae) na baía de Sepetiba, Rio de Janeiro. Rev. Bras. Biol. 59 (3), 443-454.

Azevedo, J.S., Braga, E.S., Favaro, D.T., Perretti, A.R., Rezende, C.E., Souza, C.M.M., 2011. Total mercury in sediments and in Brazilian Ariidae catfish from two estuaries under different anthropogenic influence. Mar. Pollut. Bull. 62, 2724-2731. http://dx.doi.org/10. 1016/j.marpolbul.2011.09.015.

Azevedo, J.S., Sarkis, J.E.S., Hortellani, M.A., Ladle, R.J., 2012. Are catfish (Ariidae) effective bioindicators for $\mathrm{Pb}, \mathrm{Cd}, \mathrm{Hg}, \mathrm{Cu}$ and $\mathrm{Zn}$ ? Water Air Soil Pollut. 223, 3911-3922. http://dx.doi.org/10.1007/s11270-012-1160-2.

Baršienè, J., Rybakovas, A., Lang, T., Andreikėnaitè, L., Michailovas, A., 2013. Environmental genotoxicity and cytotoxicity levels in fish from the North Sea offshore region and Atlantic coastal waters. Mar. Pollut. Bull. 68, 106-116. http://dx.doi.org/10.1016/j. marpolbul.2012.12.011.
Benincá, C., Ramsdorf, W., Vicari, T., et al., 2012. Chronic genetic damages in Geophagus brasiliensis exposed to anthropic impact in estuarine lakes at Santa Catarina coast southern of Brazil. Environ. Monit. Assess. 184, 2045-2056. http://dx.doi.org/10. 1007/s10661-011-2098-3.

Bernet, D., Schmidt, H., Meier, W., Burkhardt-Holm, P., Wahli, T., 1999. Histopathology in fish: proposal for a protocol to assess aquatic pollution. J. Fish Dis. 22, 25-34. http://dx.doi.org/10.1046/j.1365-2761.1999.00134.x.

Bradford, M.M., 1976. A Rapid and Sensitive Method for the Quantitation Microgram Quantities of Protein Utilizing the Principle of Protein-Dye Binding. Anal Biochem. 7, 248-254

Brazil, 2012. Recomendação No 05 de 25/06/2012 do Comitê Nacional de Zonas Úmidas. Brasília.

Burdena, V.M., Sandheinrich, M.B., Caldwell, C.A., 1998. Effects of lead on the growth and 6-aminolevulinic acid dehydratase activity of juvenile rainbow trout, Oncorhynchus mykiss. Environ. Pollut. 101, 285-289. http://dx.doi.org/10.1016/S0269-7491(98) 00029-3.

Buschini, A., Carboni, P., Martino, A., Poli, P., Rossi, C., 2003. Effects of temperature on baseline and genotoxicant induced DNA damage in haemocytes of Dreissena polymoha. Mutat. Res. 537, 81-92. http://dx.doi.org/10.1016/S1383-5718(03)00050-0.

Camizuli, E., Monna, F., Scheifler, R., Amiotte-Suchet, P., Losno, R., Beis, P., Alibert, P., 2014. Impact of trace metals from past mining on the aquatic ecosystem: a multi-proxy approach in the Morvan (France). Environ. Res. 134, 410-419. http://dx.doi.org/10. 1016/j.envres.2014.07.008

Carrasco, K., Tilbury, K.L., Myers, M.S., 1990. Assessment of the piscine micronucleus test as an in situ biological indicator of chemical contaminant effects. Can. J. Fish. Aquat. Sci. 47, 2123-2136.

Cavaş, T., 2008. In vivo genotoxicity of mercury chloride and lead acetate: micronucleus test on acridine orange stained fish cells. Food Chem. Toxicol. 46, 352-358. http://dx.doi.org/10.1016/j.fct.2007.08.015.

Cavaş, T., Ergene-Gözükara, S., 2005. Induction of micronuclei and nuclear abnormalities in Oreochromis niloticus following exposure to petroleum refinery and chromium processing plant effluents. Aquat. Toxicol. 74, 264-271. http://dx.doi.org/10.1016/j. aquatox.2005.06.001.

Cavas, T., Garanko, N.N., Arkhipchuk, V.V., 2005. Induction of micronuclei and binuclei in blood, gill and liver cells of fishes subchronically exposed to cadmium chloride and copper sulphate. Food Chem. Toxicol. 43, 569-574. http://dx.doi.org/10.1016/j.fct. 2004.12.014.

CEPAGRI (Centro de Pesquisas Meteorológicas e Climáticas Aplicadas à Agricultura), 2014p. Clima dos Municípios Paulistas. Avaliable from http://www.cpa.unicamp.br/ outras-informacoes/clima_muni_113.html (Accessed 15 October 2014(.

Chapman, P.M., Wang, F., 2001. Assessing sediment contamination in estuaries. Environ. Toxicol. Chem. 20, 3-22. http://dx.doi.org/10.1002/etc.5620200102.

Chou, C.L., Paon, L.A., Moffatt, J.D., et al., 2004. Distribution of contaminants in biota and sediments in the Musquash Estuary, Atlantic Canada, marine protected area site initiative and contaminant exclusion zone. Mar. Pollut. Bull. 48, 884-893. http://dx.doi.org/10.1016/j.marpolbul.2003.11.012.

Choueri, R.B., Cesar, a., Abessa, D.M.S., Torres, R.J., Riba, I., Pereira, C.D.S., Nascimento, M.R.L., Morais, R.D., Mozeto, A.A., DelValls, T. A., 2010. Harmonised framework for ecological risk assessment of sediments from ports and estuarine zones of North and South Atlantic. Ecotoxicology 19, 678-96 http://dx.doi.org/10.1007/s10646009-0442-y.

Choueri, R.B., Cesar, a, Torres, R.J., Abessa, D.M.S., Morais, R.D., Pereira, C.D.S., Nascimento, M.R.L., Mozeto, A.A., Riba, I., DelValls, T.A, 2009. Integrated sediment quality assessment in Paranaguá Estuarine System, Southern Brazil. Ecotoxicol. Environ. Saf. 72, 1824-31. http://dx.doi.org/10.1016/j.ecoenv.2008.12.005

Corsi, A.C., Landim, P.M.B., 2003. Chumbo, Zinco e Cobre em sedimentos de corrente nos Ribeirões Grande, Perau e Canoas, e Córrego Barrinha no município de Adrianopólis (Vale do Ribeira, PR). Geociências 22, 49-61.

Costa, P.M., Costa, M.H., 2007. Genotoxicity assessment in fish peripheral blood: a method for a more efficient analysis of micronuclei. J. Fish Biol. 71, 148-151. http://dx.doi.org/ 10.1111/j.1095-8649.2007.01548.x.

Costa, P.M., Lobo, J., Caeiro, S., Martins, M., Ferreira, A.M., Caetano, M., Vale, C., Delvalls, T.A., Costa, M.H., 2008. Genotoxic damage in Solea senegalensis exposed to sediments from the Sado Estuary (Portugal): effects of metallic and organic contaminants. Mutat. Res. 654, 29-37. http://dx.doi.org/10.1016/j.mrgentox.2008.04.007.

Cruz, A.F., Davanso, M.B., Araujo, G.S., Buruaem, L.M., Santaella, S.T., Cruz, A.C.F., de Morais, R.D., Abessa, D.M.S., 2014. Cumulative influences of a small city and former mining activities on the sediment quality of a subtropical estuarine protected area. Environ. Monit. Assess. 186 (11), 7035-7046. http://dx.doi.org/10.1007/s10661-014-3908-1.

Cunha-Lignon, M., Coelho-Jr, C., Almeida, R., Menghini, R., Correa, F., 2009. Mangrove forests and sedimentary processes on the south coast of São Paulo state (Brazil). J. Coast. Res. 405-409.

Davies, I.M., Vethaak, A.D., 2012. Integrated Marine Environmental Monitoring of Chemicals and Their Effects. ICES Cooperative Research ReportNo. 315 (277 pp.).

EC-European Commission, 2002. Commission Regulation N 178/2002 of 28 January 2002. Laying down the general principles and requirements of food law, establishing the European Food Safety Authority and laying down procedures in matters of food safety. Off J Eur Union Legis Ser L031, 1-24 (Available from: http://eurlex.europa. eu/LexUriServ/LexUriServ.do?uri=CELEX:32002R0178).

EC- European Commission, 2006. Commission Regulation N. 1881/2006 of 19 December 2006. Setting maximum levels of certain contaminants in foodstuff. Off. J. Eur. Union 65, 5-24 (Avaliable from: http://eur-lex.europa.eu/legal-content/EN/ALL/? uri=CELEX:32006R1881)

Environment Canada and Ministère du Développement durable, de l'Environnement et des Parcs du Québec, 2007,. Criteria for the Assessment of Sediment Quality in Quebec and Application Frameworks: Prevention, Dredging and Remediation. 
Ergene, S., Cavaș, T., Celik, A., Köleli, N., Kaya, F., Karahan, A., 2007. Monitoring of nuclear abnormalities in peripheral erythrocytes of three fish species from the Goksu Delta (Turkey): genotoxic damage in relation to water pollution. Ecotoxicology 16, 385-391. http://dx.doi.org/10.1007/s10646-007-0142-4.

Eysink, G.G.J., Pádua, H.B., Piva-Bertoletti, S.A.E., Martins, M.C., Navas-Pereira, D., 1998 Metais pesados no Vale do Ribeira e em Iguape-Cananéia. Ambiente 2 (1), 6-13.

FAO/WHO - Food and Agriculture Organization/World Health Organization, 2014r. Contaminants \& food additives. Limit test for heavy metals in food additive specifications-explanatory note. Avaliable from: http://www.fao.org/food/foodsafety-quality/scientific-dvice/jecfa/guidelines0/en/.

Fernández-Caliani, J.C., Barba-Brioso, C., González, I., Galán, E., 2009. Heavy metal pollution in soils around the abandoned mine sites of the Iberian Pyrite Belt (southwest Spain). Water Air Soil Pollut. 200, 211-226. http://dx.doi.org/10.1007/s11270-008-9905-7.

Ferraro, M.V.M., Fenocchio, A.S., Mantovani, M.S., Oliveira Ribeiro, C.A., Cestari, M.M. 2004. Mutagenic effects of tributyltin and inorganic lead (Pb II) on the fish $H$. malabaricus as evaluated using the comet assay and the piscine micronucleus and chromosome aberration tests. Genet. Mol. Biol. 27 (2), 103-107.

Fishbase, 2014. Cathorops spixii (Agassiz, 1829). http://www.fishbase.org/summary/ SpeciesSummary.php?id=960 (Accessed 30 October 2014).

Fonseca, V.F., Vasconcelos, R.P., França, S., Serafim, a., Lopes, B., Company, R., Bebianno, M.J., Costa, M.J., Cabral, H.N., 2014. Modeling fish biological responses to contaminants and natural variability in estuaries. Mar. Environ. Res. 96, 45-55. http://dx.doi.org/10. 1016/j.marenvres.2013.10.011.

Gabbianelli, R., Lupidi, G., Villarini, M., Falcioni, G., 2003. DNA damage induced by copper on erythrocytes of gilthead sea bream Sparus aurata and mollusk Scapharca inaequivalvis. Arch. Environ. Contam. Toxicol. 45, 350-356. http://dx.doi.org/10. 1007/s00244-003-2171-1.

Gagne, F., Blasé, C., 1995. Evaluation of the genotoxicity of environmental contaminants in sediments to rainbow trout hepatocytes. Environ. Toxicol. Water Qual. 10, 217-229. http://dx.doi.org/10.1002/tox.2530100309.

Galloway, T.S., Brown, R.J., Browne, M.a., Dissanayake, A., Lowe, D., Jones, M.B., Depledge, M.H., 2004. Ecosystem management bioindicators: the ECOMAN project: a multibiomarker approach to ecosystem management. Mar. Environ. Res. 58, 233-237. http://dx.doi.org/10.1016/j.marenvres.2004.03.064.

Guimarães, V., Sígolo, J.B., 2008. Associação de resíduos da metalurgia com sedimentos em suspensão-Rio Ribeira de Iguape. Rev. Inst. Geociênc. 8 (2), 1-10.

Gusso-Choueri, P.K., Choueri, R.B., de Araújo, G.S., Cruz, A.C.F., Stremel, T., Campos, S., de Sousa Abessa, D.M., Ribeiro, C.A.O., 2015. Assessing pollution in marine protected areas: the role of a multi-biomarker and multi-organ approach. Environ. Sci. Pollut. Res. Int. 22, 18047-18065. http://dx.doi.org/10.1007/s11356-015-4911-y.

Harabawy, A.S.A., Mosleh, Y.Y.I., 2014. The role of vitamins A, C, E and selenium as antioxidants against genotoxicity and cytotoxicity of cadmium, copper, lead and zinc on erythrocytes of Nile tilapia, Oreochromis niloticus. Ecotoxicol. Environ. Saf. 104, 28-35. http://dx.doi.org/10.1016/j.ecoenv.2014.02.015.

Heddle, J.A., 1973. A rapid in vivo test for chromosome damage. Mutat. Res. 18, 187-192. http://dx.doi.org/10.1016/0027-5107(73)90035-3.

Hill, R.W., Wyse, G.A., Anderson, M., 2004. External Respiration: The Physiology of Breathing. In: Hill, R.W., Wyse, G.A., Anderson, M. (Eds.), Animal Physiology, first ed. Sinauer Associates, Inc, Sunderland.

Hogstrand, C., 2012. Zinc. In: Wood, C.M., Farrell, A.P., Brauner, C.J. (Eds.), Homeostasis and Toxicology of Essential Metals. Academic, London, pp. 136-200.

Hoshina, M.M., de Franceschi de Angelis, D., Marin-Morales, M.A., 2008. Induction of micronucleus and nuclear alterations in fish (Oreochromis niloticus) by a petroleum refinery effluent. Mutat. Res. 656, 44-48. http://dx.doi.org/10.1016/j.mrgentox. 2008.07.004

IBGE- Instituto Brasileiro de Geografia e Estatística, 2014. Estimativas de população por cidades. Avaliable from: http://cidades.ibge.gov.br/xtras/home.php (Accessed 30th October 2014).

Isani, G., Andreani, G., Cocchioni, F., Fedeli, D., Carpené, E., Falcioni, G., 2009. Cadmium accumulation and biochemical responses in Sparus aurata following sub-lethal Cd exposure. Ecotoxicol. Environ. Saf. 72, 224-230. http://dx.doi.org/10.1016/j.ecoenv. 2008.04.015.

Jha, A.N., 2004. Genotoxicological studies in aquatic organisms: an overview. Mutat. Res. 552, 1-17. http://dx.doi.org/10.1016/j.mrfmmm.2004.06.034.

Kassie, F., Parzefall, W., Knasmuller, S., 2000. Single cell gel electrophoresis assay : a new technique for human biomonitoring studies. Mutat. Res. 463 (1), 13-31. http://dx.doi. org/10.1016/S1383-5742(00)00041-7.

Lee, R.F., Steinert, S., 2003. Use of the single cell gel electrophoresis/comet assay for detecting DNA damage in aquatic (marine and freshwater) animals. Mutat. Res. Mutat. Res. 544, 43-64. http://dx.doi.org/10.1016/S1383-5742(03)00017-6.

Li, Z.-H., Li, P., Randak, T., 2011. Evaluating the toxicity of environmental concentrations of waterborne chromium (VI) to a model teleost, Oncorhynchus mykiss: a comparative study of in vivo and in vitro. Comp. Biochem. Physiol. C Toxicol. Pharmacol. 153, 402-407. http://dx.doi.org/10.1016/j.cbpc.2011.01.005.

Long, E.R., MacDonald, D.D., Smith, S.L., Calder, E.D., 1995. Incidence of adverse biological effects within ranges of chemical concentrations in marine and estuarine sediments. Environ. Manag. 19, 81-97.

Mahiques, M.M.D., Burone, L., Cesar, R., Figueira, L., Oliveira, A.A.D., 2009. Anthropogenic influences in a lagoonal environment : a multiproxy approach at the Valo Grande mouth, Cananéia-Iguape System (SE Brazil). Braz. J. Oceanogr. 57 (4), 325-337.

Maranho, L.A., Pereira, C.D.S., Choueri, R.B., Cesar, A., Gusso-Choueri, P.K., Torres, R.J., et al., 2012. The application of biochemical responses to assess environmental quality of tropical estuaries: field surveys. J. Environ. Monit. 14 (10), 2608-2626. http://dx.doi. org/10.1039/c2em30465a.

Matsumoto, S.T., Mantovani, M.S., Irene, M., Malaguttii, A., Dias, A.L., Fonseca, I.C., Marinmorales, M.A., 2006. Genotoxicity and mutagenicity of water contaminated with tannery effluents, as evaluated by the micronucleus test and comet assay using the fish Oreochromis niloticus and chromosome aberrations in onion root-tips. Genet. Mol. Biol. 29, 148-158.

McGeer, J.C., Brix, K.V., Skeaff, J.M., DeForest, D.K., Brigham, S.I., Adams, W.J., Green, A., 2003. Inverse relationship between bioconcentration factor and exposure concentration for metals: implications for hazard assessment of metals in the aquatic environment. Environ. Toxicol. Chem. 22 (5), 1017-1037. http://dx.doi.org/10.1002/etc.5620220509.

Melo, S.C., Teixeira, R.L., 1992. Distribuição, reprodução e alimentação de Cathorops spixii e Arius rugispinis (Pisces: Ariidae) do complexo Mundaú/Manguaba, Maceió-AL. Braz. J. Biol. 52, 169-180.

Mitchelmore, C., Chipman, J., 1998. DNA strand breakage in aquatic organisms and the potential value of the comet assay in environmental monitoring. Mutat. Res. 399, 135-147. http://dx.doi.org/10.1016/S0027-5107(97)00252-2.

Molina-Villalba, I., Lacasaña, M., Rodríguez-Barranco, M., Hernández, A.F., GonzalezAlzaga, B., Aguilar-Garduño, C., Gil, F., 2015. Biomonitoring of arsenic, cadmium, lead, manganese and mercury in urine and hair of children living near mining and industrial areas. Chemosphere 124, 83-91. http://dx.doi.org/10.1016/j.chemosphere. 2014.11.016.

Monserrat, J.M., Martínez, P.E., Geracitano, L.A., Lund Amado, L., Martinez Gaspar Martins, C., Lopes Leães Pinho, G., Soares Chaves, I., Ferreira-Cravo, M., Ventura-Lima, J. Bianchini, A., 2007. Pollution biomarkers in estuarine animals: critical review and new perspectives. Comp. Biochem. Physiol. C Toxicol. Pharmacol. 146, 221-234. http://dx.doi.org/10.1016/j.cbpc.2006.08.012.

Monteiro, V., Cavalcante, D.G.S.M., Viléla, M.B.F.A., Sofia, S.H., Martinez, C.B.R., 2011. In vivo and in vitro exposures for the evaluation of the genotoxic effects of lead on the Neotropical freshwater fish Prochilodus lineatus. Aquat. Toxicol. 104, 291-298. http://dx.doi.org/10.1016/j.aquatox.2011.05.002.

Moraes, R., Gerhard, P., Andersson, L., Sturve, J., Rauch, S., Molander, S., 2003. Establishing causality between exposure to metals and effects on fish. Hum. Ecol. Risk Assess. An Int. J. 9, 149-169. http://dx.doi.org/10.1080/713609857.

Morais, L.G., Abessa, D.M.S., 2014. PSR framework applied to the coastal management of "Complexo Estuarino-Lagunar Iguape-Cananéia" - CELIC (São Paulo, Brazil), in terms of sanitation and public health. Gestão Costeira Integrada http://dx.doi.org/ $10.5894 /$ rgci455 (in press).

Myers, M.S., Johnson, L.L., Collier, T.K., 2003. Establishing the causal relationship between polycyclic aromatic hydrocarbon (PAH) exposure and hepatic neoplasms and neoplasia-related liver lesions in English sole (Pleuronectes vetulus). Hum. Ecol. Risk. Assess. 9, 67-94.

Nipper, M.G., Roper, D.S., Williams, E.K., Martin, M.L., 1998. Sediment toxicity and benthic communities in mildly contaminated mudflats. Environ. Toxicol. Chem. 17, 502-510. http://dx.doi.org/10.1002/etc.5620170322.

Olajire, A.A., Altenburger, R., Küster, E., Brack, W., 2005. Chemical and ecotoxicological assessment of polycyclic aromatic hydrocarbon contaminated sediments of the Niger Delta, Southern Nigeria. Sci. Total Environ. 340, 123-136. http://dx.doi.org/10. 1016/j.scitotenv.2004.08.014.

Olive, P.L., 1988. DNA precipitation assay: a rapid and simple method for detecting DNA damage in mammalian cells. Environ. Mol. Mutagen. 11, 487-495. http://dx.doi. org/10.1002/em.2850110409.

Oliveira Ribeiro, C.A., Vollaire, Y., Sanchez-chardi, A., Roche, H., 2005. Bioaccumulation and the effects of organochlorine pesticides, PAH and heavy metals in the Eel (Anguilla anguilla) at the Camargue Nature Reserve, France. 74, 53-69. http://dx.doi.org/10. 1016/j.aquatox.2005.04.008

Omar, W.A., Zaghloul, K.H., Abdel-Khalek, A.A., Abo-Hegab, S., 2012. Genotoxic effects of metal pollution in two fish species, Oreochromis niloticus and Mugil cephalus, from highly degraded aquatic habitats. Mutat. Res. 746, 7-14. http://dx.doi.org/10.1016/j. mrgentox.2012.01.013.

Orieux, N., Cambier, S., Gonzalez, P., Morin, B., Adam, C., Garnier-Laplace, J., Bourdineaud, J.P., 2011. Genotoxic damages in zebrafish submitted to a polymetallic gradient displayed by the Lot River (France). Ecotoxicol. Environ. Saf. 74, 974-983. http://dx.doi.org/10.1016/j. ecoenv.2011.01.008.

Parolini, M., Pedriali, A., Binelli, A., 2013. Chemical and biomarker responses for sitespecific quality assessment of the Lake Maggiore (northern Italy). Environ. Sci. Pollut. Res. 20 (8), 5545-5557. http://dx.doi.org/10.1007/s11356-013-1556-6.

Pellacani, C., Buschini, A., Furlini, M., et al., 2006. A battery of in vivo and in vitro tests useful for genotoxic pollutant detection in surface waters. J. Aquatic. Toxicol. 77, 1-10. http://dx.doi.org/10.1016/j.aquatox.2005.10.010.

Perra, G., Pozo, K., Guerranti, C., et al., 2011. Levels and spatial distribution of polycyclic aromatic hydrocarbons (PAHs) in superficial sediment from 15 Italian marine protected areas (MPA). Mar. Pollut. Bull. 62, 874-877. http://dx.doi.org/10.1016/j. marpolbul.2011.01.023.

Pozo, K., Lazzerini, D., Perra, G., et al., 2009. Levels and spatial distribution of polychlorinated biphenyls (PCBs) in superficial sediment from 15 Italian Marine Protected Areas (MPA). Mar. Pollut. Bull. 58, 773-776. http://dx.doi.org/10.1016/j. marpolbul.2009.03.003.

Ramsdorf, W.A., Ferraro, M.V.M., Oliveira-Ribeiro, C.A., Costa, J.R.M., Cestari, M.M., 2009 Genotoxic evaluation of different doses of inorganic lead (PbII) in Hoplias malabaricus. Environ. Monit. Assess. 158, 77-85. http://dx.doi.org/10.1007/s10661-008-0566-1.

Riba, I., Blasco, J., Jiménez-Tenorio, N., Delvalls, T.A., de Canales, M.L.G., 2005. Heavy metal bioavailability and effects: II. Histopathology-bioaccumulation relationships caused by mining activities in the Gulf of Cádiz (SW, Spain). Chemosphere 58, 671-682. http://dx.doi.org/10.1016/j.chemosphere.2004.02.016.

Rybicka, E.H., 1996. Impact of mining and metallurgical industries on the environment in Poland. Appl. Geochem. 11, 3-9.

Schmid, W., 1975. The micronucleus test. Mutat. Res. 31, 9-15.

Silva, C., Mattioli, M., Fabbri, E., Yáñez, E., DelValls, T.A., Martín-Díaz, M.L., 2012. Benthic community structure and biomarker responses of the clam, Scrobicularia plana in a 
shallow tidal creek affected by fish farm effluents (Rio San Pedro, SW Spain). Environ. Int. 47, 86-98. http://dx.doi.org/10.1016/j.envint.2012.06.008.

Singh, N.P., McCoy, M.T., Tice, R.R., Schneider, E.L., 1988. A simple technique for quantification of low levels of DNA damage in individual cells. Exp. Cell Res. 175, 184-191.

Souza, T.S., Fontanetti, C.S., 2012. DNA damage of erythrocytes of fish Oreochromis niloticus (Perciformes, Cichlidae), after acute exposure to river water receiving effluent from an oil refinery. J. Braz. Soc. Ecotoxicol. 7, 17-22. http://dx.doi.org/10.5132/ jbse.2012.02.003.

Tabachnic, B.G., Fidell, L.S., 1996. Using Multivariate Statistics. Harper Collins College Publishers, New York.

Taylor, M.P., Mould, S.A., Kristensen, L.J., Rouillon, M., 2014. Environmental arsenic, cadmium and lead dust emissions from metal mine operations: implications for environmental management, monitoring and human health. Environ. Res. 135, 296-303. http://dx.doi.org/10.1016/j.envres.2014.08.036.

Torres, R.J., Cesar, A., Pastor, V.A., et al., 2015. A critical comparison of different approaches to sediment-quality assessments in the Santos estuarine system in Brazil. Arch. Environ. Contam. Toxicol. 68 (1), 132-147. http://dx.doi.org/10.1007/s00244-014-0099-2.

USEPA - United States Environmental Protection Agency, 1994. Determination of trace elements in waters and wastes by inductively coupled plasma-mass spectrometry. Washington, Environmental Protection Agency. Method 200, 9.
Van Straalen, N.M., 2003. Ecotoxicology becomes stress ecology. Environ. Sci. Technol. 37 (17), 324-330

Wirzinger, G., Weltje, L., Gercken, J., Sordyl, H., 2007. Genotoxic damage in field-collected three-spined sticklebacks (Gasterosteus aculeatus L.): a suitable biomonitoring tool? Mutat. Res. 628, 19-30.

Witeska, M., Ko, B., 2003. The changes in common carp blood after short-term zinc exposure. Environ. Sci. Pollut. Res. 10, 284-286.

Wood, R.D., Mitchell, M., Sgouros, J., Lindahl, T., 2001. Human DNA repair genes. Science 291 (5507), 1284-1289. http://dx.doi.org/10.1126/science.1056154.

Yadav, K.K., Trivedi, S.P., 2009. Sublethal exposure of heavy metals induces micronuclei in fish, Channa punctata. Chemosphere 77, 1495-1500. http://dx.doi.org/10.1016/j. chemosphere.2009.10.022.

Zhuang, P., Lu, H., Li, Z., Zou, B., McBride, M.B., 2014. Multiple exposure and effects assessment of heavy metals in the population near mining area in South China. PLoS One 11, 9(4)-e94484. http://dx.doi.org/10.1371/journal.pone. 